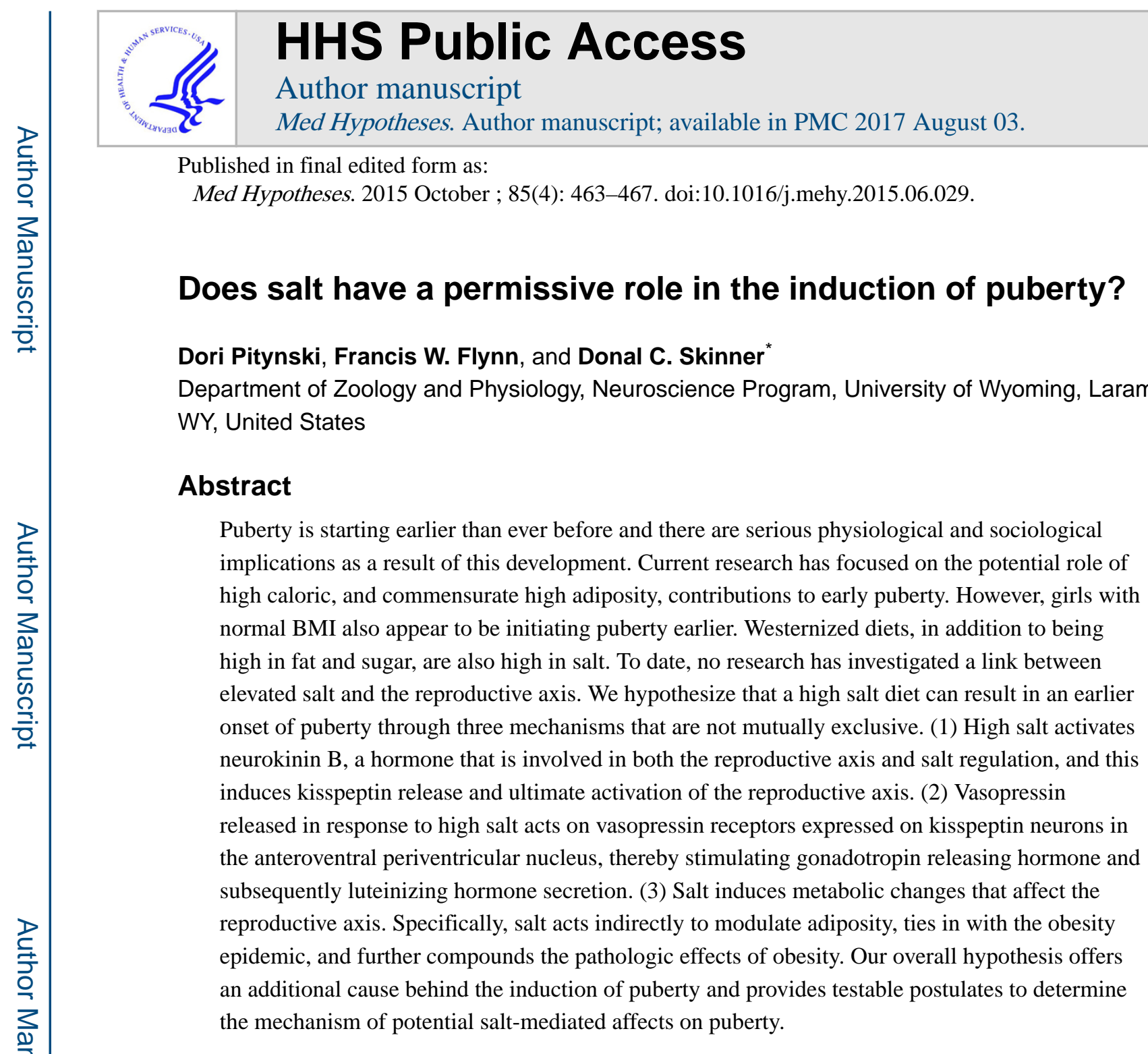

\title{
Introduction
}

There is general consensus that girls are now entering puberty at a younger age. In the US the age of puberty onset has decreased from approximately 11 years of age [1], to under 10 years of age in the most recent report [2]. Similarly, the Copenhagen Puberty Study reported that puberty in girls had advanced by a year between 1991 and 1998 [3]. These studies considered the start of breast development, thelarche, as the first marker of puberty. The age at menarche has not decreased [4]. Fewer studies have investigated the age of pubertal onset in boys but there is some evidence to suggest that puberty is also occurring earlier $[5,6]$.

Adverse psychological and physical complications can result from a decreased age at pubertal onset, including depression, stress, increased alcohol use, reproductive cancers, and obesity $[2,7-10]$.

*Corresponding author at: Dept 3166, University of Wyoming, 1000 E. University Ave., United States. Tel.: +1 (307)766 4922. dcs@ uwyo.edu (D.C. Skinner).

Conflict of interest

The authors report no conflicts of interest. 
The timing of puberty is orchestrated by a series of endogenous and exogenous signals that coordinate the activation of the hypothalamic-pituitary-gonadal axis [11]. Puberty is a heritable trait and many genes associated with puberty are thought to affect its timing $[12,13]$. Several other factors are purported to affect puberty onset, such as xenosteroids, social cues, geographic location and metabolic status [4].

Reproduction, especially in mammals, is an energy-demanding task and it is crucial for puberty to commence after the deposition of adequate energy stores. The critical mass hypothesis postulated that a critical amount of body mass and fat was essential before puberty was initiated in an animal [14]. The discovery of leptin, an adipocyte hormone, provided the putative initiating messenger [15]. Indeed, several studies reported a correlation between the early onset of puberty and body mass index (BMI) $[2,4,16]$. However, leptin fails to induce early puberty in pre-pubescent humans [13,17] and rodents [18]. Thus leptin is no longer considered a trigger for the onset of puberty, but is thought to be one of several permissive factors, whose presence may be necessary, but alone is not sufficient, to initiate sexual maturation. Moreover, the obesity epidemic [19] does not fully explain the global pubertal advancement because girls with low BMI are also entering puberty earlier [3,4]. A recent study does, however, suggest that even brief changes in BMI, not BMI per se, can affect the onset of puberty [20].

Nevertheless it is clear that citizens, obese or otherwise, of developed countries are over consuming processed foods - the so-called "western diet". This diet is high in fat, sugar, and salt [21-23]. To our knowledge, the effect, if any, of salt on puberty has not been investigated.

\section{The Salt-Puberty hypothesis}

The idea that salt is a sexual stimulant is not new [24]. Aristotle [25] recorded that "sheep administered brine (salt water) copulated sooner". Similarly, Plutarch [26] wrote "Those that breed dogs, when they find their bitches not prone to be hot, give them salt... to excite and arouse their sleeping lechery...". Aristotle [25] also noted "Some people say, indeed stoutly maintain that, if they merely lick salt, mice become pregnant." Indeed, the word salacious, meaning lustful or lecherous, is derived from the Latin word for salt, sal. Nearly 2000 years later, extremely low dietary salt concentrations $(0.01 \% \mathrm{NaCl})$ were shown to delay puberty compared to $0.05-0.09 \% \mathrm{NaCl}$ [27]. Conversely, hypernatriophilic male rats displayed an earlier advance in testicular development than control animals [28]. In pigs, a high salt diet post-partum leads to earlier resumption of estrous cyclicity [29]. The onset of puberty has decreased within this century while daily salt consumption has increased [30]. To our knowledge, a scientific link between salt and stimulation of the reproductive axis has not been investigated. We hypothesize that a diet high in salt may change the timing of puberty through three potential mechanisms that are not mutually exclusive (Fig. 1).

1. Arcuate nucleus kisspeptin-neurokinin B-dynorphin (KNDy) neurons link the reproductive system and the salt-regulatory system.

2. Salt-induced vasopressin affects anteroventral periventricular (AVPV) nucleus kisspeptin neurons. 
3. Salt affects metabolism and consequently modulates activation of the reproductive system.

\section{KNDy neurons}

Kisspeptin is a potent activator of gonadotropin-releasing hormone ( $\mathrm{GnRH})$ neurons [31] and is required for progression through puberty. At puberty, there is an increase in the number of kisspeptin neurons, overall kisspeptin tone, and an increase in kisspeptin projections onto GnRH neurons [32-34]. Mutations in either the Kiss1 gene, or Kiss1R the receptor gene, compromise pubertal maturation, and induce additional deficits in reproductive function $[35,36]$. The two main populations of kisspeptin neurons are located in the AVPV and the arcuate nucleus [37,38]. Arcuate kisspeptin neurons co-localize with neurokinin B (NKB) and dynorphin (DYN) and are termed KNDy neurons [39]. They play a major role in the activation of the reproductive axis at puberty [39]. Neurokinin B is also necessary for humans to progress normally through puberty. Humans with a loss-of-function mutation of TAC3, the gene for NKB, or TACR3, the gene for the NKB receptor, $\mathrm{NK}_{3} \mathrm{R}$, present with hypogonadatropic hypogonadism [40,41]. However, the precise role of NKB in the reproductive axis remains unclear as there is evidence of both stimulatory and inhibitory effects. Specifically, NKB has a primarily stimulatory effect on luteinizing hormone (LH) $[42,43]$. However, some reports indicate that NKB can be inhibitory to LH secretion [44]. The effect of NKB on LH release is likely determined by the precise hormonal environment [45].

$\mathrm{NKB}$ acts on $\mathrm{NK}_{3}$ receptors expressed on vasopressin neurons. $\mathrm{NK}_{3}$ receptors are activated in hypertonic conditions, causing vasopressin release [46,47]. High salt conditions increase $\mathrm{NK}_{3}$ receptor activation $[47,48]$, which may affect arcuate nucleus KNDy neurons in two ways. First, NKB in KNDy neurons may be stimulated and feed back on itself to increase kisspeptin release. Second, high salt may stimulate NKB release from cells other than KNDy neurons, but still activate $\mathrm{NK}_{3}$ receptors on KNDy neurons and stimulate kisspeptin release. If these conjectures were upheld, increased kisspeptin, NKB and LH may be evident after a salt challenge.

The medial amygdala may also provide a connection between the salt-regulatory system and the KNDy neurons of the reproductive system. The medial amygdala is implicated in reproductive behaviors, the regulation of reproductive cycles, and sex steroid receptors are abundant [49-52]. The kisspeptin receptor is also expressed within the rodent amygdala and kisspeptin expression in the medial amygdala responds to sex-steroids [53]. Injections of kisspeptin into this region stimulates LH secretion [54]. The medial amygdala is currently thought to provide a reproductive "brake" on the reproductive axis. The medial amygdala contains an established network of GABA neurons and connects to the AVPV [55,56] and, when lesioned, results in an increase in circulating LH. Injections of tachykinin agonists for the $\mathrm{NK}_{3}$ receptor into the medial amygdala inhibit salt appetite, a motivational state that drives salt consumption [57]. 


\section{Vasopressin and the reproductive system}

Vasopressin is also a well-known regulator of water balance and blood pressure. In response to hypertonic conditions, vasopressin is secreted from neurons in the paraventricular and supraoptic nuclei with axonal projections to the neurohypophysis. Chronic hyperosmolarity or salt loading increases not only vasopressin secretion, but also vasopressin gene expression in the paraventricular and supraoptic nuclei [58]. Vasopressin is also released into the interstitial fluid of the brain [59] and vasopressin concentrations in cerebrospinal fluid may even be higher than in the peripheral circulation [60]. This widespread release of vasopressin has the potential to reach kisspeptin neurons in either the AVPV or arcuate nucleus, especially as these regions are adjacent to the 3 rd cerebral ventricle. It is known in rodents that vasopressin neurons from the SCN project to kisspeptin neurons in the AVPV and are involved in the circadian timing of the preovulatory LH surge in these species [61-64]. Vasopressin is sufficient to alter LH levels within plasma. Previous studies suggest that the amount of vasopressin infused icv affects the resulting LH levels [65-67]: low doses stimulate LH release, whereas higher doses suppress it. Thus, at least in rodents, there is compelling evidence that vasopressin has an established reproductive role. We hypothesize that higher levels of vasopressin induced by a high salt diet during the pre-pubertal period could impact the timing of puberty.

\section{Salt and metabolism: an indirect effect of salt on puberty?}

The role of high dietary salt on adiposity is unclear. Fonseca-Alaniz et al. [68] reported that male rats fed a high salt $(7.8 \% \mathrm{NaCl})$ diet from weaning laid down significantly more fat, especially periepididymal fat, than controls. This effect was notable after 6 weeks but had disappeared by 9 weeks. Leptin was also elevated after 6 weeks and, assuming that this fat deposition was progressive, would encompass the pubertal transition. Coêlho et al. [69] recorded increased food intake and overall energy gain in male rats on similar high salt diets. Intriguingly this diet increased GLUT4 in white adipose tissue [70], which may explain the increased insulin-stimulated glucose uptake in adipocytes of high salt fed rats [71]. Other adipokines, such as FGF21 and/or adiponectin, may also play a central role. FGF21 has been implicated in puberty onset [72].

A relationship between salt intake and weight has also been found in humans [73,74]. Salt intake has also been strongly associated with obesity and the metabolic syndrome [75]. Moreover, Yi et al. [76] recently reported a predictive relationship between salt intake and body fatness: for each $1 \mathrm{~g}$ of salt consumed per day there was a $1.2 \%$ increase in body fatness after adjustment for energy intake. This relationship was most strongly evident in women. Thus, it is reasonable to hypothesize that the effect of salt on puberty may occur indirectly, through an effect on fat and consequently leptin or other adipokines, thereby creating a permissive environment for pubertal activation.

\section{Integration of pubertal signals}

A general question that pertains to all putative signals that are driving puberty earlier is, how do these signals work? In our salt hypothesis, it is likely that individuals will have repeated 
or continuous exposure to a high salt dietary regimen. Nevertheless it is possible that sporadic or only exposure during a critical window of development will impact pubertal onset. One hypothesis is that kisspeptin and/or NKB concentrations are increasing in response to salt, eventually breaching a threshold of exposure to initiate puberty earlier. An analogy of this is how estrogen concentrations rise above a certain threshold to trigger the preovulatory GnRH surge in the brain [77]. This hypothesis will be difficult to test directly because it has not yet been possible to measure dynamic changes in kisspeptin or NKB secretion in vivo $[78,79]$. Another hypothesis is that maturation of the neuronal systems responsible for initiating puberty may be altered in response to a high salt diet. A third conjecture is that puberty permissive signals are elevated earlier due to the high salt diet and, as soon as maturation of the neuronal systems are complete, then puberty commences. An analogous situation appears to occur in the seasonal onset of reproduction in sheep, which has been termed "seasonal puberty" [80], where melatonin concentrations must be elevated for several weeks before the reproductive system is activated [81]. This last hypothesis would also suggest that there will be a minimum age of possible onset, unless maturation itself can be driven earlier. Clearly, further research is warranted to address the unknown mechanisms underlying puberty induction as well as the means by which these mechanisms become functional.

\section{Conclusion and perspective}

The high salt content of processed foods so prevalent in developed nations has the potential to negatively impact reproductive health. Our Salt-Puberty hypothesis is intended to further our knowledge on diet influences on reproduction. If upheld, this hypothesis will have significant implications on the amount of salt consumed. Salt activation of the NKB system at the arcuate nucleus and/or the medial amygdala may induce puberty. Alternatively, vasopressin receptors on kisspeptin neurons in the AVPV or arcuate nucleus can modulate reproductive activity. Lastly, we cannot discount a more indirect pathway of salt, its effects being mediated through adipocytes and their accompanying endocrine output.

\section{Acknowledgments}

Grant support: National Institutes of General Medicine from the National Institutes of Health (Grant No. P30 GM103398).

Funding Francis W. Flynn has provided funds to support research staff and laboratory expenses related to the formulation of this hypothesis. This study was funded by the National Institutes of General Medicine from the National Institutes of Health (Grant No. P30 GM103398).

\section{References}

1. Reynolds EL. Individual differences in physical changes associated with adolescence in girls. Arch Pediatr Adolesc Med. 1948; 75(3):329.

2. Biro FM, Greenspan LC, Galvez MP, Pinney SM, Teitelbaum S, Windham GC, et al. Onset of breast development in a longitudinal cohort. Pediatrics. 2013; 132(6):1019-27. [PubMed: 24190685]

3. Aksglaede L, Sorensen K, Petersen JH, Skakkebaek NE, Juul A. Recent decline in age at breast development: the copenhagen puberty study. Pediatrics. 2009; 123(5):e932-9. [PubMed: 19403485]

4. Herman-Giddens ME. The enigmatic pursuit of puberty in girls. Pediatrics. 2013; 132(6):1125-6. [PubMed: 24190683] 
5. Tinggaard J, Mieritz MG, Sorensen K, Mouritsen A, Hagen CP, Aksglaede L, et al. The physiology and timing of male puberty. Curr Opin Endocrinol Diabetes Obes. 2012; 19(3):197-203. [PubMed: 22499221]

6. Zhou X, Zhang L. The trends of puberty onset among Chinese children. Iran J Public Health. 2015; 44(1):134-5. [PubMed: 26060785]

7. Ahlgren M, Melbye M, Wohlfahrt J, Sørensen TIA. Growth patterns and the risk of breast cancer in women. N Engl J Med. 2004; 351(16):1619-26. [PubMed: 15483280]

8. Deardorff J, Gonzales NA, Christopher FS, Roosa MW, Millsap RE. Early puberty and adolescent pregnancy: the influence of alcohol use. Pediatrics. 2005; 116(6):1451-6. [PubMed: 16322170]

9. Ge X, Conger RD, Elder GH. Coming of age too early: pubertal influences on girls' vulnerability to psychological distress. Child Dev. 1996; 67(6):3386-400. [PubMed: 9071784]

10. Li CI, Littman AJ, White E. Relationship between age maximum height is attained, age at menarche, and age at first full-term birth and breast cancer risk. Cancer Epidemiol Biomark Prev. 2007; 16(10):2144-9.

11. Sanchez-Garrido MA, Tena-Sempere M. Metabolic control of puberty: roles of leptin and kisspeptins. Horm Behav. 2013; 64(2):187-94. [PubMed: 23998663]

12. Perry JRB, Day F, Elks CE, Sulem P, Thompson DJ, Ferreira T, et al. Parent-of-origin-specific allelic associations among 106 genomic loci for age at menarche. Nature. 2014; 514(7520):92-7. [PubMed: 25231870]

13. Roa J, García-Galiano D, Castellano JM, Gaytan F, Pinilla L, Tena-Sempere M. Metabolic control of puberty onset: new players, new mechanisms. Mol Cell Endocrinol. 2010; 324(1-2):87-94. [PubMed: 20026241]

14. Frisch RE, Hegsted DM, Yoshinaga K. Body weight and food intake at early estrus of rats on a high-fat diet. Proc Natl Acad Sci USA. 1975; 72(10):4172-6. [PubMed: 1060097]

15. Ahima RS, Prabakaran D, Mantzoros C, Qu D, Lowell B, Maratos-Flier E, et al. Role of leptin in the neuroendocrine response to fasting. Nature. 1996; 382(6588):250-2. [PubMed: 8717038]

16. Biro FM, Greenspan LC, Galvez MP. Puberty in girls of the 21st century. J Pediatr Adolesc Gynecol. 2012; 25(5):289-94. [PubMed: 22841372]

17. Barash IA, Cheung CC, Weigle DS, Ren H, Kabigting EB, Kuijper JL, et al. Leptin is a metabolic signal to the reproductive system. Endocrinology. 1996; 137(7):3144-7. [PubMed: 8770941]

18. Cheung CC, Thornton JE, Kuijper JL, Weigle DS, Clifton DK, Steiner RA. Leptin is a metabolic gate for the onset of puberty in the female rat. Endocrinology. 1997; 138(2):855-8. [PubMed: 9003028]

19. Mokdad AH. The spread of the obesity epidemic in the United States, 1991-1998. JAMA. 1999; 282(16):1519. [PubMed: 10546690]

20. Salgin B, Norris SA, Prentice P, Pettifor JM, Richter LM, Ong KK, et al. Even transient rapid infancy weight gain is associated with higher BMI in young adults and earlier menarche. Int J Obes (Lond). 2015; 39(6):939-44. [PubMed: 25771929]

21. Cocores JA, Gold MS. The salted food addiction hypothesis may explain overeating and the obesity epidemic. Med Hypotheses. 2009; 73(6):892-9. [PubMed: 19643550]

22. Astrup A, Buemann B, Western P, Toubro S, Raben A, Christensen NJ. Obesity as an adaptation to a high-fat diet: evidence from a cross-sectional study. Am J Clin Nutr. 1994; 59(2):350-5. [PubMed: 7993398]

23. Bray GA, Nielsen SJ, Popkin BM. Consumption of high-fructose corn syrup in beverages may play a role in the epidemic of obesity. Am J Clin Nutr. 2004; 79(4):537-43. [PubMed: 15051594]

24. Moinier BM, Drueke TB. Aphrodite, sex and salt - from butterfly to man. Nephrol Dial Transplant. 2008; 23(7):2154-61. [PubMed: 18450831]

25. Aristotle: history of animals, vol. VI.

26. Plutarch: moralia: table talks, vol. v.

27. Ganguli MC, Smith JD, Hanson LE. Sodium metabolism and its requirement during reproduction in female rats. J Nutr. 1969; 99(2):225-34. [PubMed: 5346554] 
28. Almeida SA, Vjanna-Favaretto AL, Lamano-Carvalho TL. Sexual development of hypernatriophilic male rats up to puberty. Braz J Med Biol Res. 1996; 29(3):395-8. [PubMed: 8736136]

29. Seynaeve M, De Wilde R, Janssens G, De Smet B. The influence of dietary salt level on water consumption, farrowing, and reproductive performance of lactating sows. J Anim Sci. 1996; 74(5): 1047-55. [PubMed: 8726736]

30. Carriquiry, A., Moshfegh, AJ., Steinfeldt, LC., Cogswell, ME., Zhang, Z., Yang, Q., et al. Morbidity and mortality weekly report. Center for Disease Control and Prevention; 2013. Trends in the prevalence of excess dietray salt intake - United States 2003-2010.

31. d' Anglemont de Tassigny X, Fagg LA, Carlton MB, Colledge WH. Kisspeptin can stimulate gonadotropin-releasing hormone $(\mathrm{GnRH})$ release by a direct action at $\mathrm{GnRH}$ nerve terminals. Endocrinology. 2008; 149(8):3926-32. [PubMed: 18450966]

32. Clarkson J, Boon WC, Simpson ER, Herbison AE. Postnatal development of an estradiolkisspeptin positive feedback mechanism implicated in puberty onset. Endocrinology. 2009; 150(7): 3214-20. [PubMed: 19299459]

33. Clarkson J, Herbison AE. Postnatal development of kisspeptin neurons in mouse hypothalamus; sexual dimorphism and projections to gonadotropin-releasing hormone neurons. Endocrinology. 2006; 147(12):5817-25. [PubMed: 16959837]

34. Shahab M, Mastronardi C, Seminara SB, Crowley WF, Ojeda SR, Plant TM. Increased hypothalamic GPR54 signaling: a potential mechanism for initiation of puberty in primates. Proc Natl Acad Sci USA. 2005; 102(6):2129-34. [PubMed: 15684075]

35. Topaloglu AK, Tello JA, Kotan LD, Ozbek MN, Yilmaz MB, Erdogan S, et al. Inactivating KISS1 mutation and hypogonadotropic hypogonadism. N Engl J Med. 2012; 366(7):629-35. [PubMed: 22335740]

36. de Roux N, Genin E, Carel JC, Matsuda F, Chaussain JL, Milgrom E. Hypogonadotropic hypogonadism due to loss of function of the KiSS1-derived peptide receptor GPR54. Proc Natl Acad Sci USA. 2003; 100(19):10972-6. [PubMed: 12944565]

37. Clarkson J, d'Anglemont de Tassigny X, Colledge WH, Caraty A, Herbison AE. Distribution of kisspeptin neurones in the adult female mouse brain. J Neuroendocrinol. 2009; 21(8):673-82. [PubMed: 19515163]

38. Lehman MN, Merkley CM, Coolen LM, Goodman RL. Anatomy of the kisspeptin neural network in mammals. Brain Res. 2010; 1364:90-102. [PubMed: 20858464]

39. Lehman MN, Coolen LM, Goodman RL. Minireview: kisspeptin/neurokinin B/dynorphin (KNDy) cells of the arcuate nucleus: a central node in the control of gonadotropin-releasing hormone secretion. Endocrinology. 2010; 151(8):3479-89. [PubMed: 20501670]

40. Topaloglu AK, Reimann F, Guclu M, Yalin AS, Kotan LD, Porter KM, et al. TAC3 and TACR3 mutations in familial hypogonadotropic hypogonadism reveal a key role for Neurokinin B in the central control of reproduction. Nat Genet. 2008; 41(3):354-8. [PubMed: 19079066]

41. Young J, Bouligand J, Francou B, Raffin-Sanson M-L, Gaillez S, Jeanpierre M, et al. TAC3 and TACR3 defects cause hypothalamic congenital hypogonadotropic hypogonadism in humans. J Clin Endocrinol Metab. 2010; 95(5):2287-95. [PubMed: 20194706]

42. Li SY, Li XF, Hu MH, Shao B, Poston L, Lightman SL, et al. Neurokinin B receptor antagonism decreases luteinising hormone pulse frequency and amplitude and delays puberty onset in the female rat. J Neuroendocrinol. 2014; 26(8):521-7. [PubMed: 24863620]

43. Ramaswamy S, Seminara SB, Ali B, Ciofi P, Amin NA, Plant TM. Neurokinin B stimulates GnRH release in the male monkey (Macaca mulatta) and is colocalized with kisspeptin in the arcuate nucleus. Endocrinology. 2010; 151(9):4494-503. [PubMed: 20573725]

44. Grachev P, Li XF, Kinsey-Jones JS, di Domenico AL, Millar RP, Lightman SL, et al. Suppression of the GnRH pulse generator by neurokinin B involves a $\kappa$-opioid receptor-dependent mechanism. Endocrinology. 2012; 153(10):4894-904. [PubMed: 22903614]

45. Grachev P, Millar RP, O’Byrne KT. The role of neurokinin B signalling in reproductive neuroendocrinology. Neuroendocrinology. 2014; 99(1):7-17. [PubMed: 24356581] 
46. Hatae T, Kawano H, Karpitskiy V, Krause JE, Masuko S. Arginine-vasopressin neurons in the rat hypothalamus produce neurokinin B and co-express the tachykinin NK-3 receptor and angiotensin II type 1 receptor. Arch Histol Cytol. 2001; 64(1):37-44. [PubMed: 11310503]

47. Haley GE, Flynn FW. Tachykinin NK3 receptor contribution to systemic release of vasopressin and oxytocin in response to osmotic and hypotensive challenge. AJP. 2007; 293(2):R931-7.

48. Jensen D, Zhang Z, Flynn FW. Trafficking of tachykinin neurokinin 3 receptor to nuclei of neurons in the paraventricular nucleus of the hypothalamus following osmotic challenge. Neuroscience. 2008; 155(1):308-16. [PubMed: 18583062]

49. Bagga N, Chhina GS, Mohan Kumar V, Singh B. Cholinergic activation of medial preoptic area by amygdala for ovulation in rat. Physiol Behav. 1984; 32(1):45-8. [PubMed: 6718533]

50. Beltramino C, Taleisnik S. Facilitatory and inhibitory effects of electrochemical stimulation of the amygdala on the release of luteinizing hormone. Brain Res. 1978; 144(1):95-107. [PubMed: 565243]

51. Murray EA. The amygdala, reward and emotion. Trends Cognit Sci. 2007; 11(11):489-97. [PubMed: 17988930]

52. Simerly RB, Swanson LW, Chang C, Muramatsu M. Distribution of androgen and estrogen receptor mRNA-containing cells in the rat brain: an in situ hybridization study. J Comp Neurol. 1990; 294(1):76-95. [PubMed: 2324335]

53. Kim J, Semaan SJ, Clifton DK, Steiner RA, Dhamija S, Kauffman AS. Regulation of kiss1 expression by sex steroids in the amygdala of the rat and mouse. Endocrinology. 2011; 152(5): 2020-30. [PubMed: 21363930]

54. Comninos AN, Anastasovska J, Sahuri-Arisoylu M, Li X, Li S, Hu M, et al. Kisspeptin signaling in the amygdala modulates reproductive hormone secretion. Brain Struct Funct. 2015

55. Canteras NS, Simerly RB, Swanson LW. Organization of projections from the medial nucleus of the amygdala: a PHAL study in the rat. J Comp Neurol. 1995; 360(2):213-45. [PubMed: 8522644]

56. Keshavarzi S, Sullivan RKP, Ianno DJ, Sah P. Functional properties and projections of neurons in the medial amygdala. J Neurosci. 2014; 34(26):8699-715. [PubMed: 24966371]

57. Massi M, Gentili L, Perfumi M, de Caro G, Schulkin J. Inhibition of salt appetite in the rat following injection of tachykinins into the medial amygdala. Brain Res. 1990; 513(1):1-7. [PubMed: 1693538]

58. Kondo N. Osmoregulation of vasopressin release and gene transcription under acute and chronic hypovolemia in rats. AJP. 2003; 286(3):337E-46E.

59. Landgraf R, Neumann ID. Vasopressin and oxytocin release within the brain: a dynamic concept of multiple and variable modes of neuropeptide communication. Front Neuroendocrinol. 2004; 25(34):150-76. [PubMed: 15589267]

60. Kagerbauer SM, Martin J, Schuster T, Blobner M, Kochs EF, Landgraf R. Plasma oxytocin and vasopressin do not predict neuropeptide concentrations in human cerebrospinal fluid. $\mathrm{J}$ Neuroendocrinol. 2013; 25(7):668-73. [PubMed: 23574490]

61. Kriegsfeld LJ, Leak RK, Yackulic CB, LeSauter J, Silver R. Organization of suprachiasmatic nucleus projections in Syrian hamsters (Mesocricetus auratus): an anterograde and retrograde analysis. J Comp Neurol. 2003; 468(3):361-79.

62. Vida B, Deli L, Hrabovszky E, Kalamatianos T, Caraty A, Coen CW, et al. Evidence for suprachiasmatic vasopressin neurones innervating kisspeptin neurones in the rostral periventricular area of the mouse brain: regulation by oestrogen. J Neuroendocrinol. 2010; 22(9):1032-9. [PubMed: 20584108]

63. Watson RE, Langub MC, Engle MG, Maley BE. Estrogen-receptive neurons in the anteroventral periventricular nucleus are synaptic targets of the suprachiasmatic nucleus and perisuprachiasmatic region. Brain Res. 1995; 689(2):254-64. [PubMed: 7583329]

64. Williams WP, Jarjisian SG, Mikkelsen JD, Kriegsfeld LJ. Circadian control of kisspeptin and a gated GnRH response mediate the preovulatory luteinizing hormone surge. Endocrinology. 2011; 152(2):595-606. [PubMed: 21190958]

65. Cates PS, Forsling ML, O’byrne KT. Stress-induced suppression of pulsatile luteinising hormone release in the female rat: role of vasopressin. J Neuroendocrinol. 1999; 11(9):677-83. [PubMed: 10447806] 
66. Palm IF, van der Beek EM, Wiegant VM, Buijs RM, Kalsbeek A. Vasopressin induces a luteinizing hormone surge in ovariectomized, estradiol-treated rats with lesions of the suprachiasmatic nucleus. Neuroscience. 1999; 93(2):659-66. [PubMed: 10465449]

67. Salisbury RL, Krieg RJ, Seibel HR. Effects of arginine vasotocin, oxytocin, and arginine vasopressin on steroid-induced surges of luteinizing hormone and prolactin in ovariectomized rats. Eur J Endocrinol. 1980; 94(2):166-73.

68. Fonseca-Alaniz MH, Brito LC, Borges-Silva CN, Takada J, Andreotti S, Lima FB. High dietary sodium intake increases white adipose tissue mass and plasma leptin in rats. Obesity. 2007; 15(9): 2200-8. [PubMed: 17890487]

69. Coêlho MS, Passadore MD, Gasparetti AL, Bibancos T, Prada PO, Furukawa LL, et al. High- or low-salt diet from weaning to adulthood: effect on body weight, food intake and energy balance in rats. Nutr Metab Cardiovasc Dis. 2006; 16(2):148-55. [PubMed: 16487915]

70. Prada PDO, Okamoto MM, Furukawa LNS, Machado UF, Heimann JC, Dolnikoff MS. High- or low-salt diet from weaning to adulthood: effect on insulin sensitivity in wistar rats. Hypertension. 2000; 35(1):424-9. [PubMed: 10642336]

71. Fonseca-Alaniz MH, Takada J, Andreotti S, de Campos TBF, Campaña AB, Borges-Silva CN, et al. High sodium intake enhances insulin-stimulated glucose uptake in rat epididymal adipose tissue. Obesity. 2008; 16(6):1186-92. [PubMed: 18369340]

72. Owen BM, Bookout AL, Ding X, Lin VY, Atkin SD, Gautron L, et al. FGF21 contributes to neuroendocrine control of female reproduction. Nat Med. 2013; 19(9):1153-6. [PubMed: 23933983]

73. Song HJ, Cho YG, Lee H-J. Dietary sodium intake and prevalence of overweight in adults. Metabolism. 2013; 62(5):703-8. [PubMed: 23357528]

74. Zhu H, Pollock NK, Kotak I, Gutin B, Wang X, Bhagatwala J, et al. Dietary sodium, adiposity, and inflammation in healthy adolescents. Pediatrics. 2014; 133(3):e635-42. [PubMed: 24488738]

75. Hoffmann IS, Cubeddu LX. Salt and the metabolic syndrome. Nutr Metab Cardiovasc Dis. 2009; 19(2):123-8. [PubMed: 18556187]

76. Yi SS, Firestone MJ, Beasley JM. Independent associations of sodium intake with measures of body size and predictive body fatness. Obesity. 2014; 23(1):20-3. [PubMed: 25294369]

77. Moenter SM, Caraty A, Locatelli A, Karsch FJ. Pattern of gonadotropin-releasing hormone $(\mathrm{GnRH})$ secretion leading up to ovulation in the ewe: existence of a preovulatory GnRH surge. Endocrinology. 1991; 129:1175-82. [PubMed: 1874164]

78. Smith JT, Rao A, Pereira A, Caraty A, Millar RP, Clarke IJ. Kisspeptin is present in ovine hypophysial portal blood but does not increase during the preovulatory luteinizing hormone surge: evidence that gonadotropes are not direct targets of kisspeptin in vivo. Endocrinology. 2008; 149(4):1951-9. [PubMed: 18162520]

79. Caraty A, Lomet D, Sebert ME, Guillaume D, Beltramo M, Evans NP. Gonadotrophin-releasing hormone release into the hypophyseal portal blood of the ewe mirrors both pulsatile and continuous intravenous infusion of kisspeptin: an insight into kisspeptin's mechanism of action. J Neuroendocrinol. 2013; 25(6):537-46. [PubMed: 23387514]

80. Ebling, FJ., Foster, DL. Seasonal breeding - a model for puberty. In: Delamarrevan de Wall, HA.Plant, TM.van Rees, GP., Shoemaker, J., editors. Control of the Onset of Puberty III. Amsterdam: Excerpta Medica; 1990. p. 253-64.

81. O'Callaghan D, Karsch FJ, Boland MP, Roche JF. What photoperiodic signal is provided by a continuous-release melatonin implant? Biol Reprod. 1991; 45:927-33. [PubMed: 1805996] 


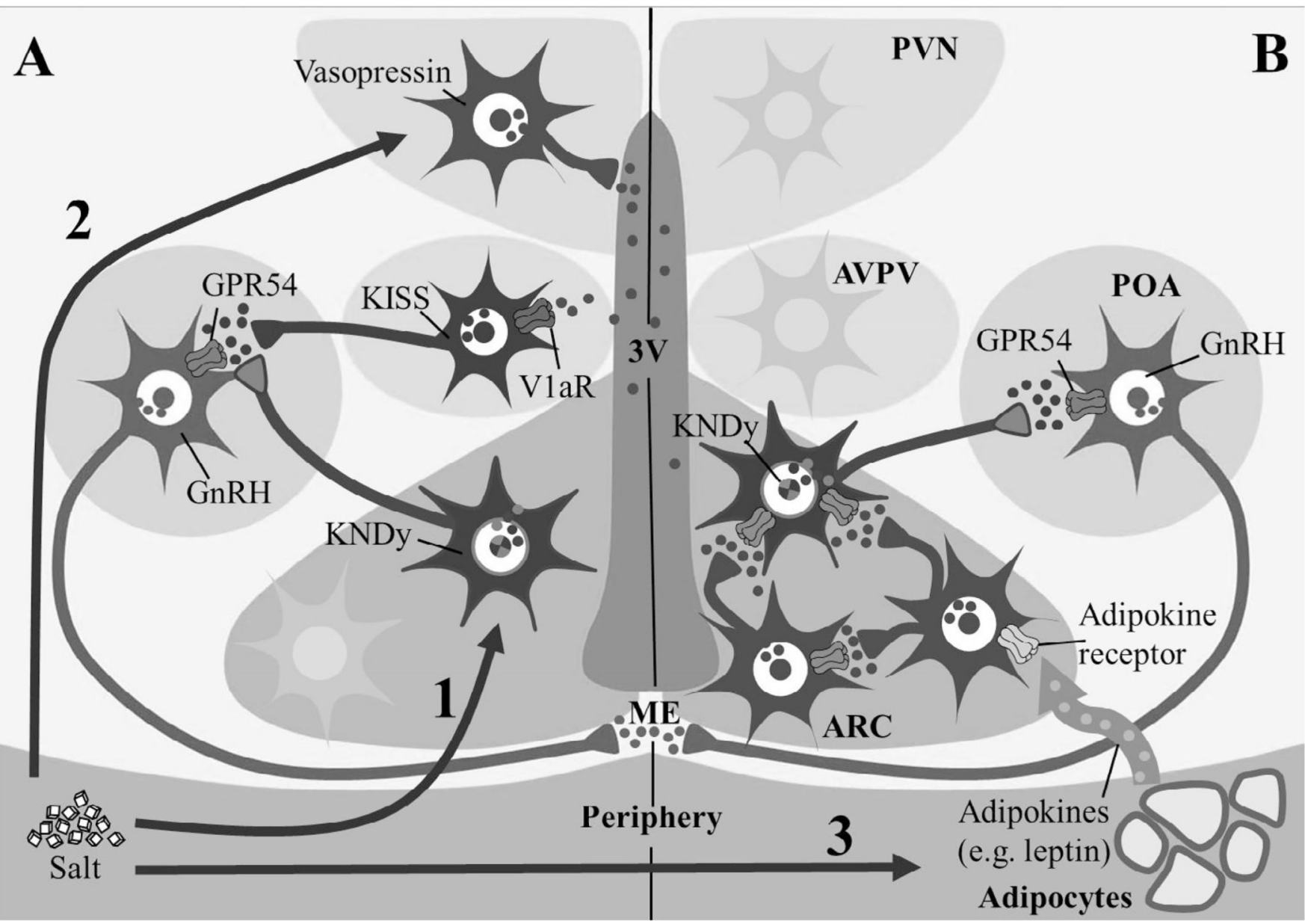

Fig. 1.

Schematic of the Salt-Puberty hypothesis illustrating 3 different, but not mutually exclusive, physiological pathways through which salt may affect puberty. (1) Salt activates KNDy neurons by stimulating release of NKB, either from KNDy neurons or local NKB neurons. $\mathrm{NKB}$ binds to $\mathrm{NK}_{3} \mathrm{R}$ leading to kisspeptin release which activates GPR54 receptors on GnRH neurons. (2) Salt stimulates release of vasopressin into 3rd ventricle, which activates its receptor, V1aR, on kisspeptin neurons in the AVPV that activate GnRH neurons. (3) Adipoctye released adipokines (e.g. leptin) which activate adipokine receptors. Adipokine receptor expressing neurons either directly or indirectly contact KNDy neurons to drive the effects of salt on puberty. 